\title{
Cold Plasma Treatment for the Control of Alternaria solani causing Early Blight of Tomato
}

\author{
K. P. Ragupathi ${ }^{1 *}$, P. R. Renganayaki ${ }^{1}$, S. Sundareswaran ${ }^{1}$, \\ Chetan Jariwala $^{2}$, S. Mohan Kumar ${ }^{3}$ and A. Kamalakannan ${ }^{4}$ \\ ${ }^{1}$ Department of Seed Science \& Technology, ${ }^{3}$ Center for Plant Molecular Biology \& \\ Biotechnology, ${ }^{4}$ Department of Plant Pathology, TNAU, Coimbatore, Tamil Nadu, India \\ ${ }^{2}$ Institute for Plasma Research, Gujarat, India \\ *Corresponding author
}

\section{A B S T R A C T}

\section{Keywords}

Cold plasma, Radio frequency, Tomato, Alternariasolani, Early blight

\section{Article Info}

Accepted: 12 December 2020 Available Online: 10 January 2021
Plasma (fourth state of matter) is ionized gas composed of positive and negative ions, electrons, neutrals, molecules, photons and UV rays. Plasma seed treatment is an emerging new technique for seed quality control. Effect of cold plasma treatment on the control of Alternaria solani (Ellis and Martin) Jones and Grout causing early blight of tomato (Solanum lycopersicum L.) cultivar PKM 1 was studied. The seeds were exposed to various durations of non-thermal (cold plasma) atmospheric air pressure plasma treatment using radio frequency glow discharge technique at Institute for Plasma Research, Gujarat, India. The seeds pre-inoculated with A.solani were plasma treated with power of $20 \mathrm{~W}$ and $40 \mathrm{~W}$ for varied durations of $0,5,10,15,20,25$ and 30 minutes. Plasma treatment significantly reduced pathogen incidence and increased both germination and plant growth in comparison with the control. Experimental results indicated that all the treatments were significantly different and the seeds treated with $40 \mathrm{~W}$ for 30 minutes showed minimum percent disease incidence $(0.0 \%)$ with highest percent disease inhibition over control (100 $\%)$. It also recorded the highest plant biometrics viz., germination (96\%), root length $(14.41 \mathrm{~cm})$, shoot length $(7.56 \mathrm{~cm})$ and vigour index $(2109)$.

\section{Introduction}

Plasma, the fourth state of matter, is an ionized gas. In 1929, Tonks and Langmuir coined the term 'Plasma'. It composed of positive and negative ions, electrons, neutrals, molecules, photons and UV radiation. Nonthermal plasma is characterized by low energy of its heavy particles (ions, molecules), which means it does not damage thermally sensitive material, but its electrons reach sufficient energy to participate in plasma-chemical reactions. Non-thermal atmospheric pressure plasma treatment is a modern biotechnological method that may be used for the decontamination of various surfaces of living tissue due to its highly reactive composition, it can treat surfaces without the need for invasive chemicals (Brelles, 2012 and Baier et al., 2014). The 
problem of poor or slow germination can be solved through many techniques and one of them is plasma treatment. Plasma treatment has become an important factor widely used in biotechnology, medicine \&food industry (Padureanu, 2012). Dry seed treatment like plasma treatment is employed to increase the seed coat permeability without increasing the moisture content of seed. Plasma seed treatment method is a physio-chemical method which has the potential to improve germination, increase the yield and kill fungal spores which is present on the seed coat (Zhou et al., 2012). Plasma treatment has been successfully applied in agriculture for seed quality improvement, seed enhancement and pathogenic micro-organisms inactivation (Filatova et al., 2013). Crop yields are improved by treating the seeds in a low temperature plasma discharge generated between spaced electrodes connected to a source of high frequency electrical power (Krapivina et al., 1994). Cold plasma treatment is a cost effective method that has been effectively used in seed technology because it is fast economic and pollution free method to improve the seed performance, it decontaminates the pathogens from seeds, no loss of seed quality and a quick treatment with no side effects. Tomato (Solanum lycopersicum Mill.) is one of the most important vegetables. The fungus Alternaria solani (Ellis and Martin) Jones and Grout is the causal agent of early blight disease, is a major pathogen of tomato causing considerable yield loss. Based on the available information cold plasma treatment on disinfection, germination and vigour of tomato cultivar PKM 1 seeds was studied.

\section{Materials and Methods}

Effect of cold plasma treatment on the control of Alternaria solani (Ellis and Martin) Jones and Grout causing Early blight of tomato (Solanum lycopersicum L.) cultivar PKM 1 was studied by following the below methodologies.

\section{Isolation of pathogen and Pathogenicity test}

The pure culture of Alternaria solani was obtained by single spore isolation method and sub culture was used for pathogenicity test by following Koch's postulate. The pathogenicity test was carried by preinoculation with spore suspension and homogenized mycelial bits of $A$. solani on foliage of 30 days old plants of PKM 1 cultivar of tomato. After inoculation, the symptoms appeared on inoculated leaves as brown, oval or angular necrotic spots with concentric rings and surrounded by a border of yellow host tissue. The fungus was reisolated and purified culture from these artificially infected leaves was similar to that of original culture. The plants which were not inoculated with the fungal spore suspension did not show any symptoms of the disease. Thus pathogenicity on tomato was confirmed (Prathima et al., 2018)

\section{Seed inoculation}

Tomato seeds were immersed in a solution of $10 \%$ commercial bleach with Tween20 (1 drop/100 $\mathrm{mL}$ of solution) for $15 \mathrm{~min}$, followed by 2 rinses with sterile distilled water for 5 minutes. After that, they were immersed in hydrogen peroxide $(33 \%)$ for 10 min and rinsed three times with sterile distilled water for 10 minutes. Later, seeds were stirred in water for $24 \mathrm{~h}$ and then airdried in a laminar flow cabin for at least $2 \mathrm{~h}$. Spores of $A$. solani were obtained by scraping a 7-day-old culture of a fungus colony growing on PDA at $25{ }^{\circ} \mathrm{C}$, adding $0.5 \% \mathrm{KCl}$ +1 drop of Tween 20 and filtered through two layers of cheese cloth. The concentration was adjusted to give a spore suspension of $10^{3}$ spores $/ \mu \mathrm{L}$. Seeds were immersed and stirred 
in this spore suspension for $30 \mathrm{~s}$ and then air dried used for plasma treatment (EviraRecuenco, et al., 2015)

\section{Plasma device and Plasma treatment}

Non-thermal (cold plasma) atmospheric air pressure plasma treatment using radio frequency glow discharge technique at Institute for Plasma Research, Gujarat, India was used at a base pressure of $0.05 \mathrm{~m}$ bar, operating pressure of $0.2 \mathrm{~m}$ bar, voltage of $500 \mathrm{~V}$, current of $0.2 \mathrm{~A}$ and power of $20 \mathrm{~W}$ and $40 \mathrm{~W}$ for varied durations of $0,5,10,15$, 20, 25 and 30 minutes. Tomato seeds were spread in glass petri dish $(150 \mathrm{~mm}$ in diameter), and they were kept into the plasma apparatus. Seeds were exposed to inductive plasma treatment with RF discharge. Mean while, without plasma treatment, control seeds were also exposed to the same vacuum as the treated seeds (Cherry et al., 2018).

\section{Standard Blotter Method}

Detection of seed borne fungi in seed samples was done by following ISTA procedures. In this method, three layers of blotter paper was soaked in sterilized water and placed in the petri plates. 100 seeds were sterilized in $0.2 \%$ Sodium hypochlorite solution for 2 to 3 minutes and seeds taken randomly from each sample and were placed in petri plates and incubated for seven days in the laboratory under alternating cycles of $12 \mathrm{hrs}$ light and 12 hrs darkness. The incubated seeds were examined under stereo binocular microscope to ascertain the presence of fungi (ISTA, 1993).

\section{Germination (\%)}

Four replicates of 100 seeds were uniformly placed on standard germination paper rolltowel medium and kept in germination room maintained at $25 \pm 2^{\circ} \mathrm{C}$ and $90 \pm 2$ per cent relative humidity. After 14 days, the seedlings were evaluated as total number of normal seedlings and germination as percentage (ISTA, 1993).

\section{Root length and Shoot length}

On fourteenth day, ten normal seedlings per replication from roll towel medium were carefully removed at random from each treatment. The root length was measured from the base to the top of the primary root and the shoot length was measured from the base of the shoot to tip of primary leaf and the mean value was calculated and expressed in $\mathrm{cm}$ (ISTA, 1993).

\section{Vigour index}

The Vigour index was calculated and compared by adopting the following formula and expressed as whole number (Abdul-Baki and Anderson, 1973).

\section{Statistical analysis}

The data obtained from various experiments were analysed statistically by adopting the procedure described by Panse and Sukhatme (1985).The laboratory experiments were laid out in completely randomized design (CRD). The data recorded on per cent values were arc-sine transformed before analysis and the critical differences (CD) were calculated at 5 per cent probability level.

\section{Results and Discussion}

Standard blotter method for detection of seed borne fungi in seed samples was done by following ISTA procedures. The results indicate that all the treatments were significantly different with varied level of pathogen infection. Among the different cold plasma treatments tomato seeds treated with $40 \mathrm{~W}$ performed better than $20 \mathrm{~W}$ and the 
seeds treated with $40 \mathrm{~W}$ for $30 \mathrm{~min}$ recorded the minimum percent disease incidence $(0.0$ $\%$ ) with highest percent disease inhibition over control (100 \%) (Table 1).It also recorded the highest plant biometrics viz., germination $(96 \%)$, root length $(14.41 \mathrm{~cm})$, shoot length $(7.56 \mathrm{~cm})$ and vigour index (2109). Control recorded the minimum plant biometrics viz., germination $(61 \%)$, root length $(12.92 \mathrm{~cm})$, shoot length $(6.17 \mathrm{~cm})$ and vigour index (1164) (Table 2).

Table.1 Effect of Cold plasma treatment on tomato $c v$. PKM 1 seeds inoculated with Alternaria solani

\begin{tabular}{|c|c|c|c|c|}
\hline \multirow[t]{2}{*}{ Cold Plasma } & \multicolumn{2}{|r|}{$20 \mathrm{~W}$} & \multicolumn{2}{|r|}{$40 \mathrm{~W}$} \\
\hline & $\begin{array}{c}\text { SBM \% } \\
\text { infection } \\
(\%)\end{array}$ & $\begin{array}{l}\text { Per cent Inhibition } \\
\text { over control }(\%)\end{array}$ & $\begin{array}{c}\text { SBM \% } \\
\text { infection } \\
(\%)\end{array}$ & $\begin{array}{l}\text { Per cent Inhibition } \\
\text { over control }(\%)\end{array}$ \\
\hline 5 minutes & 82.50 & 17.50 & 39.23 & 60.77 \\
\hline 10 minutes & 77.87 & 22.13 & 31.14 & 68.86 \\
\hline 15 minutes & 71.29 & 28.71 & 23.72 & 76.28 \\
\hline 20 minutes & 60.02 & 39.98 & 17.45 & 82.55 \\
\hline 25 minutes & 53.37 & 46.63 & 9.26 & 90.74 \\
\hline 30 minutes & 45.34 & 54.66 & 0.00 & 100.00 \\
\hline Control & 100.00 & _- & 100.00 & _- \\
\hline SEd & 2.01 & 0.75 & 0.41 & 1.43 \\
\hline C D $(P=0.05)$ & 4.30 & 1.64 & 0.87 & 3.12 \\
\hline
\end{tabular}

*SBM - Standard Blotter Method

Table.2 Effect of Cold plasma treatment on biometrics of tomato $c v$. PKM 1 seeds inoculated with Alternaria solani

\begin{tabular}{|c|c|c|c|c|c|c|c|c|}
\hline \multirow{2}{*}{$\begin{array}{l}\text { Cold } \\
\text { Plasma }\end{array}$} & \multicolumn{4}{|c|}{$20 \mathrm{~W}$} & \multicolumn{4}{|c|}{$40 \mathrm{~W}$} \\
\hline & $\begin{array}{c}\text { Germi } \\
\text { nation } \\
(\%)\end{array}$ & $\begin{array}{l}\text { Shoot } \\
\text { length } \\
\text { (cm) }\end{array}$ & $\begin{array}{l}\text { Root } \\
\text { length } \\
\text { (cm) }\end{array}$ & $\begin{array}{l}\text { Vigour } \\
\text { Index }\end{array}$ & $\begin{array}{c}\text { Germi } \\
\text { nation } \\
(\%)\end{array}$ & $\begin{array}{l}\text { Shoot } \\
\text { length } \\
\text { (cm) }\end{array}$ & $\begin{array}{c}\text { Root } \\
\text { length } \\
\text { (cm) }\end{array}$ & $\begin{array}{l}\text { Vigour } \\
\text { Index }\end{array}$ \\
\hline 5 minutes & 71 & 6.25 & 13.05 & 1370 & 82 & 6.99 & 13.96 & 1718 \\
\hline 10 minutes & 74 & 6.31 & 13.27 & 1449 & 83 & 7.15 & 14.01 & 1756 \\
\hline 15 minutes & 76 & 6.59 & 13.52 & 1528 & 88 & 7.23 & 14.17 & 1883 \\
\hline 20 minutes & 77 & 6.71 & 13.63 & 1566 & 91 & 7.42 & 14.27 & 1974 \\
\hline 25 minutes & 79 & 6.84 & 13.78 & 1629 & 92 & 7.45 & 14.38 & 2008 \\
\hline 30 minutes & 82 & 6.97 & 13.94 & 1715 & 96 & 7.56 & 14.41 & 2109 \\
\hline Control & 61 & 6.17 & 12.92 & 1164 & 61 & 6.17 & 12.92 & 1164 \\
\hline SEd & 1.33 & 0.14 & 0.24 & 36.94 & 1.60 & 0.17 & 0.24 & 26.66 \\
\hline $\begin{array}{c}C D \\
(\mathbf{P}=\mathbf{0 . 0 5})\end{array}$ & 2.85 & 0.31 & 0.52 & 79.23 & 3.44 & 0.36 & 0.51 & 57.17 \\
\hline
\end{tabular}


Non-thermal plasma generated using air DBD significantly reduced fungal inoculation of Gibberella fujikuroi from rice seed surface (Yo et al., 2014) and total growth inhibition of Fusarium nivale and $F$. culmorum was observed (Zahoranova et al., 2016). The seeds of some plant species usually germinate well after non-thermalplasma treatment, e.g. some grains (Hertwig et al., 2017 and Dubinov et al., 2000); Chenopodium album agg. and Papaver somniferum (Sera et al., 2009 and 2013); Zea mays (Henselova et al., 2012); Pisum sativum (Stolarik et al., 2015); Brassica napus (Puligundla et al., 2017); Raphanus sativus (Mihai et al., 2014). In addition to improving seed germination by breaking the dormancy, cold plasma treatment has previously been reported to inactivate seed-borne pathogenic microorganisms (Selcuk et al., 2008 and Schnabel et al., 2012). Several studies have shown that lowtemperature plasma can inhibit the growth of food pathogens (Dasan et al., 2016 and Butscher et al., 2016) in addition to phytopathogenic fungi (Zhang et al., 2014). Mitra et al., 2014, found that a significant reduction of the seed-borne microbial contamination of non-thermal plasma treatment in chickpea seeds (Cicer arietinum).The increased plant growth is attributed to increased auxin metabolism, cell wall plasticity and permeability of cell membrane, increasing photosynthates and rapid cell elongation (Sadavarte and Gupta, 1963).

Not only the chemical structure but also the roughness of the surface is affected by the plasma treatment, which can change the wettability of the surface (Dubinov et al., 2000).Reason may be removal of thin lipid layer due to exposure of seeds to plasma treatment, which makes the seed hydrophilic thereby improving the germination and seed quality (Sera et al., 2010). It is a cost effective and ecologically sustainable method.
In conclusion the fast acting, economically viable and environmentally friendly techniques are needed to control plant disease during agricultural activities. Cold plasma technology is a new promising technology for phytopathogen control and has many advantages over traditional methods viz., activation of endogenous substances in seeds, rejuvenation, promotion of plant growth and maximization of yield.

\section{Acknowledgements}

The authors thank Institute for Plasma Research, Gandhinagar, Gujarat, India for providing all the facilities to perform the study.

\section{References}

Abdul-Baki AA, Anderson JD (1973) Vigour determination in soybean seed by multiple criteria. Crop Sci 13: 630-633.

Baier, M. M. Gorgen, J. Ehlbeck, D. Knorr, W. B. Herppich, and O. Schlueter, 2014. Non-thermal atmospheric pressure plasma: Screening for gentle process conditions and antibacterial efficiency on perishable fresh produce. Innov. Food Sci. Emerg.Technol. 22, 147.

Brelles, M. G. 2012. Biological and Environmental Application of Gas Discharge Plasmas, California State Polytechnic University, CA, USA.

Butscher D, Loon HV, Waskow A, von Rohr PR, Schuppler M. 2016. Plasma in activation of microorganisms on sprout seeds in a dielectric barrier discharge. Int J Food Microbiol 2016;238:222e32.

Cherry Nalwa, Ashok K. Thakur and Amit Vikram. 2018. Effect of Plasma Treatment on Growth Parameters and Seed Quality of Bell Pepper (Capsicum annuиmL.) under Field Conditions. Int.J.Curr.Microbiol.App.Sci. 7(09): 
745-751.

Dasan BG, Boyaci IH, Mutlu M. 2016. Inactivation of aflatoxigenic fungi (Aspergillus spp.) on granular food model, maize, in an atmospheric pressure fluidized bed plasma system. Food Control 2016;70:1e8.

Dubinov AE, Lazarenko EM, Selemir VD, 2000. Effect of glow discharge air plasma on grain crops seed.IEEE Transactions on Plasma Science, 28(1): 180-183.

Dubinov, A. E., E. M. Lazarenko, and V. D. Selemir, 2000. Effect of glow discharge air plasma on grain crops seed.IEEE Trans. Plasma Sci. 28, 180.

Evira-Recuenco, M. E. Iturritxa, and R. Raposo, 2015. Impact of seed transmission on the infection and development of Pitch Canker Disease in Pinusradiata.Forests 6, 3353.

Filatova I, Azharonok V, Lushkevich V, Zhukovsky A, Gadzhieva G, Spasic K, Zivkovic S and Puac N, Plasma seeds treatment as a promising technique for seed germination improvement. International Conference on Phenomena in Ionized Gases.2013, pp.14-19.

Henselova, M., L. Slovakova, M. Martinka, and A. Zahoranova, 2012. Growth, anatomy and enzyme activity changes in maize roots induced by treatment of seeds with low-temperature plasma. Biologia, 67, 490.

Hertwig, C., A. Leslie, N. Meneses, K. Reineke, C. Rauh, and O. Schluter, 2017. Inactivation of Salmonella enteritidis PT30 on the surface of unpeeled almonds by cold plasma. Innov. Food Sci. Emerg.Technol. 44, 242.

ISTA (1993) Proceedings of International Seed Test Association, International Rules for Seed Testing. Seed SciTechnol 21: 1152.
Krapivina SA, Alexander KF, Tatiana NL and Andrei B, Gas plasma treatment of plant seeds.United States Patent.1994, pp. 5456.

Mihai, A. L., D. Dobrin, M. Magureanu, and M. E. Popa, 2014.Positive effect of nonthermal plasma treatment on radish seeds. Rom. Rep. Phys. 66, 1110.

Mitra, A., Y. F. Li, T. G. Klämpfl, T. Shimizu, J. Jeon, G. E. Morfill, and J. L. Zimmermann, 2014. Inactivation of surface-borne microorganisms and increased germination of seed specimen by cold atmospheric plasma.Food Bioprocess.Technol. 7, 645.

Padureanu S. 2012. Influence of cold plasma produced by GlidArc without water vapor, upon the cells division in Triticum aestivum. Lucrari Stiintice. 2012;55(2):119- 124.

Panse, V. G. and P. V. Sukatme. 1985. Statistical methods for agricultural workers. ICAR publication, New Delhi, 359.

Prathima P, Thiruvudainambi S, Kalpana K. Molecular Characterization of Alternaria alternata(Fr.) Keissler Causing Leaf Blight Disease of Marigold. Int. J Pure App. Biosci. 2018; 6(6):1286-1291.

Puligundla, P., J. W. Kim, and C. Mok, 2017. Effect of corona discharge plasma jet treatment on decontamination and sprouting of rapeseed (Brassica napus L.) seeds.Food Control, 71, 376.

Sadavarte KT and Gupta PK, 1963.Effect of seed treatment with plant growth regulators on germination, growth and yield of brinjal.The Punjab Horticulture Journal, 2: 195-199.

Schnabel U, Niquet R, Krohmann U, Winter J, Schluter O, Weltmann KD, Ehlbeck J. 2012 Decontamination of microbiologically contaminated specimen by direct and indirect plasma treatment. Plasma Process Polymers 
2012;9: 569e75.

Selcuk M, Oksuz L, Basaran P. 2008. Decontamination of grains and legumes infected with Aspergillus spp. and Penicillum spp. by cold plasma treatment. Bioresource Technol 2008;99:5104e9.

Sera B, Spatenka P, Sery M, Vrchotova N and Hruskova I, 2010. Influence of plasma treatment on wheat and oat germination and early growth. IEEE Plasma Science, 38(10): 2963-2967.

Sera, B., I. Gajdova, M. Sery, and P. Spatenka, 2013.New physicochemical treatment method of Poppy seeds for agriculture and food industries.Plasma Sci. Technol. 15, 935.

Sera, B., M. Sery, V. Stranak, P. Spatenka, and M. Tichy, 2009.Does cold plasma change the seed dormancy? Study on seeds of Lambs Quarters (Chenopodium album agg.). Plasma Sci. Technol.11, 750.

Stolarik, T., M. Henselova, M. Martinka, O. Novak, A. Zahoranova, and M. Cernak, 2015. Effect of low temperature plasma on the structure of seeds, growth and metabolism of endogenous phytohormones in Pea (Pisumsativum
L.).Plasma Chem. Plasma Process.35, 659.

Yo, Y. K., J. Cho, T. C. Tsai, D. Staack, M. H. Kang, J. H. Roh, D. B. Shin, W. Cromwell, and D. Gross, 2014. A nonthermal plasma seed treatment method for management of a seedborne fungal pathogen on rice seed. Crop Sci. 54, 796.

Zahoranova, A., M. Henselova, D. Hudecova, B. Kalinakova, D. Kovacik, V. Medvecka, and M. Cernak, 2016. Effect of cold atmospheric pressure plasma on the wheat seedlings vigor and on the inactivation of microorganisms on the seeds surface.Plasma Chem. Plasma Process.36, 397.

Zhang X, Liu D, Zhou R, Song Y, Sun Y, Zhang Q, Niu J, Fan H, Yang SZ. 2014. Atmospheric cold plasma jet for plant disease treatment. Appl Phys Lett 2014;104:043702.

Zhou ZW, Huang YF, Yang S and Xiong D, Applicational effects of an atmospheric pressure plasma device. Progress in Electromagnetics Research Symposium Proceedings, 2012, 23(1): 1577-1580.

\section{How to cite this article:}

Ragupathi, K. P., P. R. Renganayaki, S. Sundareswaran, Chetan Jariwala, S. Mohan Kumar and Kamalakannan, A. 2021. Cold Plasma Treatment for the Control of Alternaria solani causing Early Blight of Tomato. Int.J.Curr.Microbiol.App.Sci. 10(01): 1450-1456. doi: https://doi.org/10.20546/ijcmas.2021.1001.172 